\title{
USLUB AL-INSYA DALAM QS. AL-MAIDAH \\ (KAJIAN ANALISIS BALAGAH)
}

\author{
Marhaban \\ H. M. Rusydi Khalid \\ Hj. Amrah Kasim \\ Program Magister Pascasarjana Prodi Bahasa dan Sastra Arab \\ Universitas Islam Negeri Alauddin Makassar \\ email: ebienbasogmail.com
}

\begin{abstract}
Abstrak: The purpose of this reseach is to analyse form and meaning of uslub insya' in surah al-maidah. This reseach is using the descriptive method of content analysis. The procedur of data analysis includes tables and classification of $u s l u b$ insya'. The result of this reseach reveals that there are 68 verses of uslub insya' in surah al-Maidah. Those are amar (command) 27 verses, nahi (prohibition) 14 verses, istifham (question) 9 verses, nida' (call) 16 verses, and tamanni (hope) 2 verses.

According to its form, uslub insya' in surah al-Maidah has several forms including amar (command), nahi (prohibition), istifham (question), nida' (call), and tamanni (hope). Based on the meaning, uslub insya' has two meanings. The first is denotative (haqiqi) and the second is connotative (idhafi). Denotative means the sentence expression does not have a certain purpose, while connotative means the sentence has a certain purpose depends on the context and the situation expressed by the sentence.

The other meanings of uslub insya' that can be found in the verses of surah almaidah are ta'jiz (weaken), iltimas (expression to the same age), tahdid (threat), irsyad (guidance), doa (prayer), taubikh (insult), and taqrir (confirmation).

$$
\begin{aligned}
& \text { الملخص: يهدف هذا البحث الكيفي إلى تحليل أسلوب الإنشاء و أنواعه و معانيه في سورة المائدة. أما طريقة }
\end{aligned}
$$

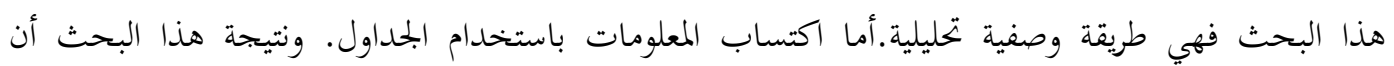

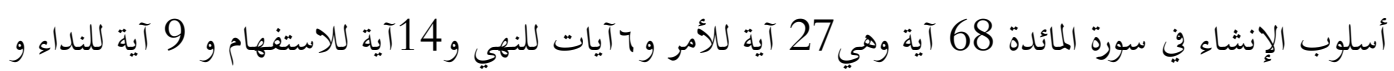

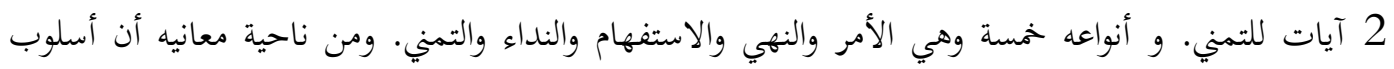

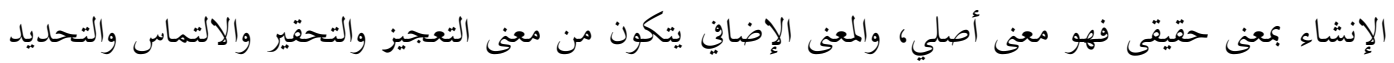

$$
\begin{aligned}
& \text { والإرشاد والتقرير والتعجب والتقرير وغير ذلك. }
\end{aligned}
$$

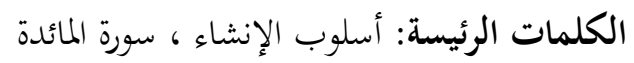

Abstrak: Tesis ini merupakan penilitian terhadap QS al-Maidah dengan memfokuskan kepada bentuk-bentuk analisis uslub insya dengan menjadikan disiplin ilmu balagah sebagai tolak ukur. 
Metode yang digunakan dalam penelitian ini adalah: metode kualitatif melalui pendekatan bahasa yaitu kaidah bahasa Arab ilmu balagah untuk dianalisa dalam QS. al-Maidah. Pemilihan apsek ini menjadi fokus penelitian berangkat dari adanya fenomena pemisah kajian nahwu, sharaf dan balagah yang memiliki kemiripan pembahasan pada objek kajian uslub insya. Analisis terhadap qur'an surah al-Maidah tampak sangat memperhatikan makna yang terkandung dibalik uslub insya. Oleh sebab itu, penulis dalam mengkaji uslub tersebut tidak hanya melihat dari aspek struktur dan pola pembentukannya semata, akan tetapi lebih jauh mempertimbangkan aspek makna.

Hasil penelitian ini, dapat dikemukakan bahwa uslub insya' dalam Surat alMaidah 68 ayat yaitu amar (perintah) 27, nahi (larangan) 14 ayat, istifham (pertanyaan) 9, nida' (panggilan) 16, dan tamanni (harapan) 2 ayat. Adapun dilihat dari segi bentuknya, ayat-ayat Surat al-Maidah terdapat berbagai bentuk uslub insya' yang meliputi amar (perintah), nahi (larangan), istifham (pertanyaan), nida' (panggilan), dan tamanni (harapan). Adapun dari segi makna uslub insya' mempunyai makna haqiqi yaitu makna asli dan makna idhafi di antaranya adalah ta'jiz (melemahkan), iltimas (ungkapan kepada yang sebaya), tahdid (ancaman), irsyad (petunjuk), dan doa (permohonan), taubikh (menghina) dan taqrir (penegasan).

Key words: Uslub Insya', Surah Al-Maidah

\section{Pendahuluan}

Dalam memahami al-Quran umat Islam harus memahami bahasanya juga, yaitu bahasa Arab. Bahasa yang digunakan al-Quran sangatlah indah, namun hanya orang tertentu saja yang bisa menikmatinya. Hal ini karena berbagai disiplin ilmu yang harus dikuasai untuk memahami al-Quran, di antaranya ilmu Sharaf, Nahwu, I'lal dan Balaghah. Al-Ghulayayniy menyatakan, turunnya alQuran dan Hadits melahirkan tiga belas ilmu, yaitu: Sharaf, I'rab, Nahwu, Rasm, Ma'ani, Bayan, Badi', Urdh, Qawafi, Ghard Syi'ir, Insya', Khithobah, Sejarah Sastra dan Kajian Bahasa.

Dalam pandangan ilmu Ma'ani, uslub insya'terbagi menjadi dua yaitu,insya thalabi dan insya ghairu thalabi, akan tetapi peneliti memfokuskan penelitian insya thalabi saja. Uslub insya thalabi adalah kalimat yang menghendaki terjadinya sesuatu yang belum terjadi pada waktu kalimat itudiucapkan. Uslub insya' thalabi ada yang berupa amar (kalimat perintah), nahi (kalimat larangan), istifham (kalimat pertanyaan), nida' (kalimat panggilan), tamanni (kalimat harapan). Masing-masing jenis Uslub insya' thalabi ini mempunyai macam-macam makna selain makna asli.

Oleh karena itu, tujuan dari penelitian ini adalah untuk mendeskripsikan (1)Ayat-ayat yang mengandung uslub insya' dalam Surat al-Maidah, (2)Bentuk uslub insya dalam Surat al-Maidah, (3)Makna yang terdapat dalam uslub insya' dalam Surat al-Maidah.

Dalam penelitian ini surat yang dijadikan sebagai objek penelitian adalah Surat al-maidah karena dalam Surat al-maidah terdapat ayat-ayat yang 
menjelaskan 1.Keimanan; bantahan terhadap orang-orang yang mempertuhankan Nabi 'Isa as. 2.Hukum-hukum; keharusan memenuhi perjanjian, hukum melanggar syiar Allah, makanan yang dihalalkan dan yang diharamkan, hukum mengawini wanita ahli kitab, wudhu', tayammum, mandi, hukum membunuh orang, hukum mengacau dan mengganggu keamanan, hukum qisas, hukum melanggar sumpah dan kafaratnya, hukum khamar, berjudi, berkorban utuk berhala, mengundi nasib, hukum membunuh binatang waktu ihram, hukum persaksian dalam berwasiat. 3. Kisah-kisah; kisah nabi Musa as menyuruh kaumnya memasuki palestina, kisah Habil dan Qabil, kisah tentang Nabi Isa as ${ }^{1}$.

Penelitian ini membahas uslub insya' thalabi secara menyeluruh yang meliputi uslub insya' thalabi amar (kalimat perintah), nahi (kalimat larangan), istifham (kalimat pertanyaan), nida' (kalimat panggilan), tamanni (kalimat harapan). Judul penelitian yang dipilih oleh penulis adala uslub al-insya' dalam QS. al-Maidah.

\section{Kajian Teoritik}

\section{Ilmu Balagah}

Kalimat bagi orang Arab adalah senjata paling tajam yang dapat diperlihatkan di depan para musuh. Karenanya, perhatian mereka terhadap ilmu balagah sangat besar. Melihat pentingnya ilmu balagah bagi bangsa Arab dan para peneliti naskah-naskah yang berbahasa Arab, khususnya naskah-naskah agama (Alquran dan hadis), maka mereka harus memberi perhatian lebih pada pemahaman ilmu Balagah untuk mengetahui esensi ilmu tersebut.

Kata balāgah, menurut bahasa, memiliki banyak arti, di antaranya alwusūl yang berarti "tiba di tempat tujuan" dan al-intihā yang berarti "berakhir". Berdasarkan pengertian ini dapat dikatakan بََْْنُ الغايَّة yang berarti "saya telah mencapai tujuan", jika saya sampai ke sana. Tujuan dari sesuatu adalah akhirnya. Sedangkan redaksi رَجْلْ بَلَّيْن berarti “seseorang ucapannya fasih dan ungkapan lisannya sesuai dengan isi hati". Al-balāg memiliki makna "objek yang bisa sampai dengannya" dan "memperoleh sesuatu sesuai keinginan". 3 Jadi balagah, menurut pengertian bahasa (etimologi), adalah keinginan yang sampai kepada tujuan dan tepat sasaran. ${ }^{4}$

\footnotetext{
${ }^{1}$ Al-Qur'an dan terjemahannya Kedalam Bahasa Indonesia . (Arab Saudi: Riyad, 1971), h. 155 .

${ }^{2}$ Ahmad Mustafā al-Marāgìy, 'Ulūm al-Balāgah: al-Bayān, al-Ma'ānī, al-Badì' (tanpa data), h. 13 .

${ }^{3}$ Rābih Dūd, al-Balāgah 'inda al-Mufassirìn hattā Nihāyat al-Qarn al-Rābi' al-Hijrìy (Cet. I; Kairo: Dār al-Fajr li al-Nasyr wa al-Tauzi', 1997), h. 15. Bandingkan dengan Jārullah Abū al-Qāsim Mahmūd ibn 'Umar al-Zamakhsyarìy, Asās al-Balāgah (Beirut : Dār al-Fikr, 1989), h. 50 .

${ }^{4}$ Rabī'ìy Muhammad 'Ali 'Abd al-KhāTiq, al-Balāgah al-'Arabiyyah wasāiluhā wa Gāyatuhā fí al-Taswìr al-Bayānìy (Alexandria: Dār al-Ma'rifah al-Jāmi’iyyah, 1989), h. 3. AlSayyid Ahmad al-Hāsyimìy, Jawāhir al-Balāgah (Beirut: Dār al-Fikr, 1994), h. 28.
} 
Setiap studi memiliki bidang kajian tertentu yang berusaha menyingkap fenomena secara teratur, tergantung pada klasifikasi dan abstraksi. Sebagaimana diketahui bahwa ilmu balagah merupakan salah satu kajian dari gramatika bahasa Arab yang membahas tentang uslüb (gaya bahasa) bahasa Arab itu sendiri, baik secara lisan maupun tulisan. Adapun dari segi bentuk dan isi, para pakar balagah membagi ilmu tersebut menjadi tiga bidang kajian, yaitu ilmu al-ma'āni, albayān, dan al-badi'.

Jika ketiga bidang kajian ilmu balagah tersebut dianggap sebagai satu tema, maka tema tersebut selayaknya memiliki kaitan kuat dengan pemakaian gaya bahasa $u s l \bar{u} b$. Hal itu dipersepsikan sebagai rumz (tanda) yang dipergunakan untuk membuka tabir makna. Tetapi jika ketiga kajian ilmu tersebut dianggap sebagai tiga tema yang berbeda, maka masing-masing kajian memiliki tema tertentu.

Jelasnya, pembahasan ilmu al-ma'ānỉ mendekati ilmu nahwu dan ilmu albayān mendekati penjelasan kebahasaan (fiqh al-lugah), karena keduanya, baik ilmu al-ma'āni dan ilmu al-bayān, masing-masing secara khusus memperhatikan kata yang bermakna tunggal (mufrad).

Sedangkan ilmu al-badì' berkisar pada kajian al-bayān (yang berkaitan dengan aksesoris maknawi), dan juga membahas petunjuk-petunjuk tertentu yang dekat dengan pembahasan al-fasāhah pada kajian ilmu al-ma'āni, seperti susunan kalimat yang rancu, tidak enak didengar, kompleksitas kata, dan lain sebagainya. Berikut ini dipaparkan secara ringkas objek kajian ilmu al-bayān, al-ma'ānìy, dan al-badi,

Pembagian ilmu al-balagah dapat dilihat dari skema berikut ini:

Skema 2.1

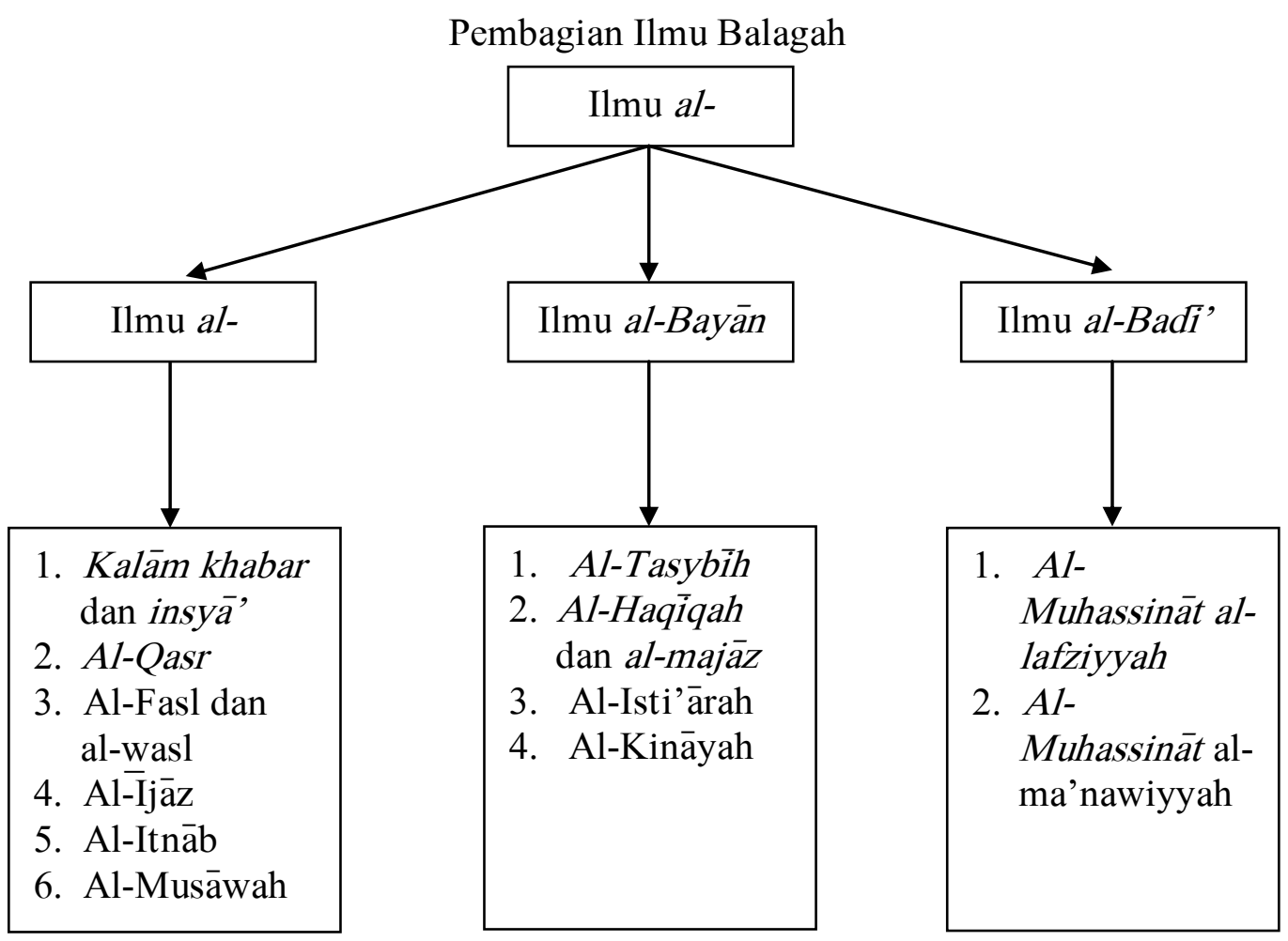


Skema 2.1 di atas menunjukkan bahwa ilmu balagah dibagi menjadi tiga bagian, yaitu al-ma'āniy, al-bayān, dan al-badi'. Kajian al-ma'ānìy meliputi enam hal, yakni kalām khabar dan insyā', al-qasr, al-fasl dan al-wasl, al-ïja.z, al-itnāb, dan al-musāwah. Kajian al-bayān meliputi empat, yakni al-tasybīh, al-haqīqah dan al-majāz, al-isti'ārah, dan al-kinàyah. Dan kajian al-badi' meliputi dua hal, yakni al-muhassināt al-lafziyyah dan al-muhassinàt al-ma'nawiyyah.

\section{Uslub al-Insya}

Kata "إنشاء” Merupakan bentuk mashdar dari “أنشأُ". Secara leksikal, kata tersebut bermakna membangun, memulai, kreasi, asli, menulis, dan menyusun. Sedangkan menurut terminolog uslüb insyā', sebagai kebalikan dari khabar merupakan bentuk kalimat yang setelah kalimat tersebut dituturkan, kita tidak bisa menilai benar atau dusta. ${ }^{5}$

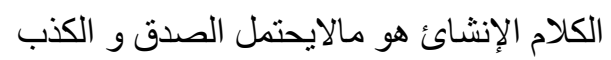

Artinya:

“kalām insyā' adalah suatu kalimat yang tidak bisa disebut benar atau dusta.

Jika seorang mutakallim mengucapkan suatu kalām insyä', mukhätab tidak bisa menilai bahwa ucapan mutakallim itu benar atau dusta. Jika seorang berkata "اسْدعع", kita tidak bisa mengatakan bahwa ucapannya itu benar atau dusta. Setelah kalām tersebut diucapkan, maka yang mesti kita lakukan adalah menyimak ucapannya.

Secara garis besar uslūb insyā', ada dua jenis yaitu insyā', thalabi dan insyā' ghair thalabi. Yang termasuk kategori insyā' thalabi adalah amar, nahy, istifhām, nidā', dan tamanni. Sedangkan yang termasuk kategori ghair thalabi adalah ta'ajjub, madāh dan zamm, qasam, dan kata-kata yang diawali dengan af'ālu al-rajā. Jenis kedua ini tidak termasuk dalam kajian ilmu ma'āni sehingga yang akan diuraikan hanyalah jenis yang pertama yaitu insyä' thalabi. ${ }^{6}$

Insyā' thalabi menurut para pakar balagah adalah suatu kalām yang menghendaki adanya suatu tuntutan yang tidak terwujud ketika kaläm itu diucapkan. ${ }^{7}$ Dari definisi di atas tampak bahwa kalām insyä thalabi terkandung suatu tuntutan. Tuntutan tersebut belum terwujud ketika ungkapan tersebut diucapkan. Kalimat-kalimat yang termaksud kategori insyā' thalabi adalah:

\section{Amar}

Secara leksikal amar bermakna 'perintah'. Sedangkan dalam terminologi ilmu balagah, amar adalah :

$$
\text { طلب الفعل على المخاطب على وجه الإستعلاء }
$$

Artinya:

"Tuntutan mengerjakan sesuatu yang lebih rendah."

\footnotetext{
${ }^{5}$ Basyuni Abd al-Fattah Fayud, 'Ilmu Ma'ani... Jilid II, h. 79.

${ }^{6}$ Al-Maidāni, op. cit., Jilid I, h. 224-228.

${ }^{7}$ Al-Maidāni, op. cit., Jilid I, h.228.
} 
Al-hāsyimi mendefinisikan jumlah al-amar (kalimat perintah) sebagai tuturan yang disampaikan oleh pihak yang lebih tinggi kedudukannya kepada pihak yang lebih rendah agar meleksanakan suatu perbuatan.

\section{Nahȳ}

Makna nahȳ secara leksikal adalah melarang, menahan, dan menentang. Sedangkan dalam terminologi ilmu balagah, nahȳ adalah:

$$
\text { طلب الكفّ عن الفعل على وجه الإستعلاء }
$$

Artinya:

"Tuntutan meninggalkan suatu perbuatan dari pihak yang lebih tinggi."

Yakni mencegah berbuat dengan perasaan tinggi pada orang yang mencegah seperti cegahan komandan kepada bawahannya. Untuk kata larangan ini hanya ada satu shigah (bentuk) yaitu: fi'il mudhari yang disertai lam nahiyah.

\section{Istifhām}

Kata "استفهم" Secara leksikal kata tersebut bermakna meminta pemahaman/meminta pengertian. Secara istilah istifhām bermakna:

Artinya:

"Menuntut pengetahuan tentang sesuatu."

Menuntut pengetahuan akan sesuatu yang sebelumnya belum diketahui yaitu dengan perantaraan salah satu alat/perabot dari beberapa alatnya. Katakata yang digunakan untuk istifhām ini ialah:

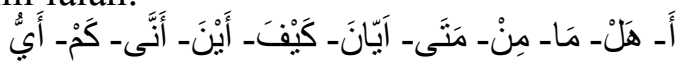

Suatu kalimat yang menggunakan kata tanya dinamakan jumlah istifhāmiyyah, yaitu kalimat yang berfungsi untuk meminta informasi tentang sesuatu yang belum diketahui sebelumnya dengan menggunakan salah satu huruf istifhām .

\section{Nidā (panggilan)}

Secara leksikal nida artinya panggilan. Sedangkan dalam terminologi ilmu balagah, nida adalah :

$$
\text { النداء هو طلب الإقبال بِحرف نائب مناب "أنادى" أدعو "ةالمنقول من الخبر إلى الإنشاء الإختصاص }
$$

Artinya:

"Nidā adalah tuntutan mutakallim yang menghendaki seseorang agar menghadapnya. Nidā menggunakan huruf yang mengganti lafadz "unādi atau ad'ü" yang susunannya dipindah dari kalām khabari menjadi kalām insyā', i."

Huruf-huruf nidāa ada delapan, yaitu: hamzah (s), ay (أى), yà (آى), $\bar{a} I$

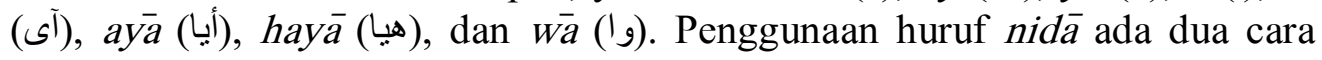
dalam mengunakannya, yaitu:

a) hamzah (ع) dan ay (أي) untuk munāda yang dekat.

\footnotetext{
${ }^{8}$ Basyuni Fayud, Ilmu al-Ma'ani... Jilid II, h. 101
} 
b) selain hamzah (أي) dan ay), semuanya digunakan untuk munāda yang jauh. Khusus untuk yā (يا) digunakan untuk seluruh munāda (yang dipanggil), baik dekat maupun jauh.

\section{Tamannì}

Kalimat tamanni (berangan-angan) adalah kalimat yang berfungsi untuk menyatakan keinginan terhadap sesuatu yang disukai, tetapi tidak mungkin untuk dapat meraihnya, seperti:

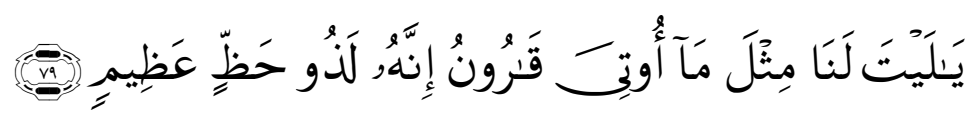

Artinya:

"Ingin rasanya kami memiliki apa yang diberikan kepada Qarun. Sesungguhnya dia benar-benar memperoleh keberuntungan yang besar."

(QS. al-Qashash: 79)

Dalam terminologi ilmu balāghah, tamann̄i adalah:

Artinya:

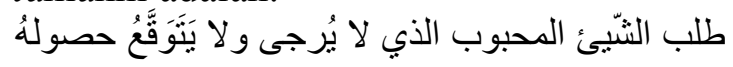

"Menuntut sesuatu yang diinginkan, akan tetapi tidak mungkin terwujud. Ketidakmungkinan terwujudnya sesuatu itu bisa terjadi karena mustahil terjadi atau juga sesuatu yang mungkin akan tetapi tidak maksimal dalam mencapaianya."

\section{III.Metodologi Penelitian}

Penelitian ini bertujuan untuk mendeskripsikan secara sistematis uslub insya' dalam Surat al-Maidah. Oleh karena itu, penelitian ini menggunakan metode analisis isi (content analisis). Alasan yang mendukung digunakannya analisis isi sebagai rancangan dalam penelitian ini adalah: (a) sumber data dalam penelitian ini berupa dokumen, (b) masalah yang dianalisis adalah isi komunikasi, (c) dan tujuan dalam penelitian ini adalah untuk mendeskripsikan isi komunikasi dan membuat inferensi.

Berdasarkan pada rumusan masalah dan tujuan penelitian yang telah ditetapkan oleh peneliti bahwa data dalam penelitian ini adalah uslub insya' yang terdapat dalam ayat-ayat al-Quran Surat al-Maidah. Sedangkan sumber datanya adalah ayat-ayat al-Quran Surat al-Maidah yang terdiri atas 120 ayat. Instrumen dalam penelitian ini berupa tabel penjaringan data, guna menjaga keabsahan data dalam penelitian ini.

Data-data yang diperoleh diolah berdasarkan teknik analisis data kualitatif untuk menganalisis data yang telah terkumpul, langkah yang dilakukan adalah (1)Menandai ayat yang mengandung uslub insya' thalabi (2)Memasukkan ke dalam tabel jenis uslub insya' (3)Mengklasifikasikan bentuk uslub insya' thalabi dengan menggunakan tabel(4)Mengklasifikasikan huruf istifham dan nida' dengan 
menggunakan tabel(5)Mengklasifikasikan makna uslub insya' thalabi dengan menggunakan tabel (6)Membahas hasil penelitian (7)Menyimpulkan

\section{IV.Hasil Penelitian dan Pembahasan}

Surat al-Maidah, memuat ayat-ayat yang mengandung uslub insya yang terdiri atas (1)amar/perintah $=27$ ayat, (2)nahi/larangan $=14$ ayat, (3) istifham/pertanyaan $=9$ ayat, (4)nida/panggilan $=16$ ayat, dan (5) tamanni/harapan $=2$ ayat.

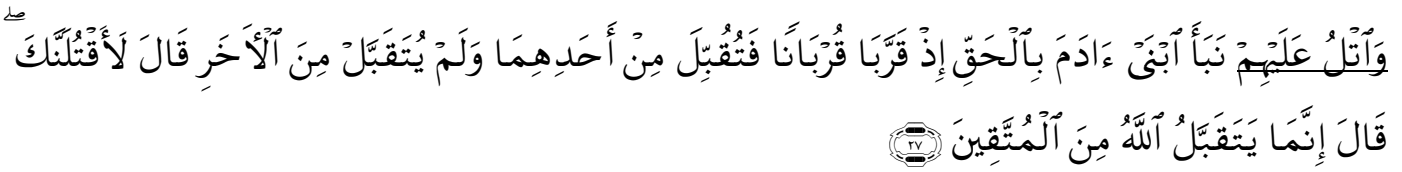

"Ceritakanlah kepada mereka kisah kedua putera Adam (Habil dan Qabil) menurut yang Sebenarnya, ketika keduanya mempersembahkan korban, Maka diterima dari salah seorang dari mereka berdua (Habil) dan tidak diterima dari yang lain (Qabil). ia Berkata (Qabil): "Aku pasti membunuhmu!". Berkata Habil: "Sesungguhnya Allah Hanya menerima (korban) dari orang-orang yang bertakwa".

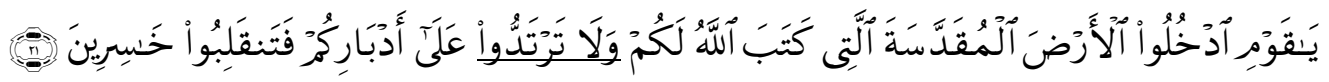

"Hai kaumku, masuklah ke tanah Suci (Palestina) yang Telah ditentukan Allah bagimu dan janganlah kamu lari kebelakang (karena takut kepada musuh), Maka kamu menjadi orang-orang yang merugi”.

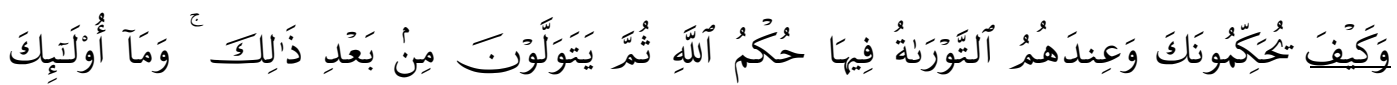

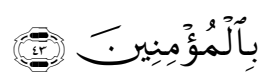

" Dan bagaimanakah mereka mengangkatmu menjadi hakim mereka, padahal mereka mempunyai Taurat yang didalamnya (ada) hukum Allah, Kemudian mereka berpaling sesudah itu (dari putusanmu)? dan mereka sungguh-sungguh bukan orang yang beriman".

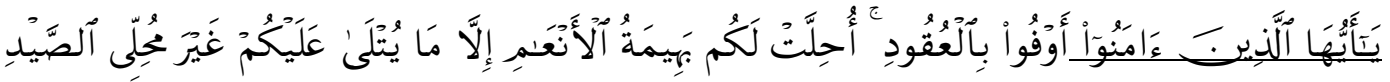

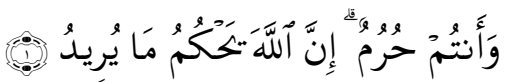

"Hai orang-orang yang beriman, penuhilah aqad-aqad itu dihalalkan bagimu binatang ternak, kecuali yang akan dibacakan kepadamu. (yang demikian itu) dengan tidak menghalalkan berburu ketika kamu sedang mengerjakan haji. Sesungguhnya Allah menetapkan hukum-hukum menurut yang dikehendakiNya".

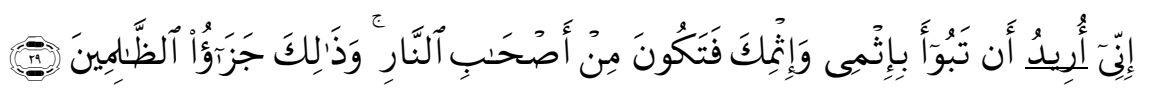


"Sesungguhnya Aku ingin agar kamu kembali dengan (membawa) dosa (membunuh)ku dan dosamu sendiri, Maka kamu akan menjadi penghuni neraka, dan yang demikian Itulah pembalasan bagi orang-orang yang zalim."

Dalam Surat al-Maidah, terdapat ayat-ayat yang mengandung bentuk $u s l u b$ insya' amar yaitu fi'il amar dan fi'il mudhari' didahului lam amar. Menurut AlGhalayaini (2000:33) fi'il amar adalah sesuatu yang menunjukkan pekerjaan $(f i$ 'il) dari seorang pelaku (fa'il) tanpa lam amar. Contoh اجتهد، جئ.تعلم . Sedangkan menurut Nadwi (1986:34) fi'il amar adalah tiap-tiap fi'il (kata kerja) yang menunjukkan arti perintah dan menerima nun taukid (nun untuk menguatkan kalimat) contoh احترمناعملن. Sedangkan fi'il mudhari' Menurut Dayyab, dkk (1990:5) adalah $f i$ 'il yang menunjukkan kejadian sesuatu pada waktu berbicara لم يكتب dan pasti didahului dengan huruf mudharaah (أنيت). Adapun fi'il mudhari' yang didahului dengan lam amar, seperti ليكتب "Tulislah", mempunyai arti perintah.

Selain itu, surat al-Maidah juga terdapat ayat-ayat yang mengandung bentuk uslub insya' nahi, istifham, nida' dan tamanni. Redaksi untuk bentuk nahi hanya satu yaitu fi'il mudhari, yang didahului dengan la nahi (Al-Jarim dan Usman, 1998:263; Al-Hasyimi, 1960: 83; Kulaib dan Shaleh, 1990). Ayat-ayat surat al-Maidah juga mengandung huruf-huruf istifham yaitu هل ,ما , أ, ,كم ,من , أي dan كيف, dan hanya terdapat satu bentuk huruf nida' yaitu يا كو 2 bentuk kata tamanni yaitu ليت dan لو لو

Sebagaimana yang dijelaskan oleh penulis sebelumnya bahwa bentuk Insya telah keluar dari makna asli kemakna lain yang dipengaruhi oleh bentuk ucapan dan menunjukan makna lain yang dapat dipahami dari susunan kalimat serta kondisi dan situasinya, dalam memudahkan dalam memahami makna dari bentuk Shigah Insya, maka perlu merujuk kepada spesifikasi berikut:

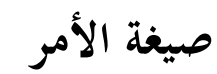

\begin{tabular}{|c|c|c|c|c|}
\hline المعنى المراد & كلمة الأمر & ه & رقم & الرقم \\
\hline الوجوب والندب & اذكروا & واذكروا اسم الله عليه & 4 & 1 \\
\hline الوجوب والندب & فاغسلوا & وهكم & 6 & .2 \\
\hline الوجوب والندب & وامسحوا & يوا برووسكى & 6 & .3 \\
\hline الوجوب والندب & فتيمّموا & فتيمّموا صعيدا & 6 & .4 \\
\hline
\end{tabular}




\begin{tabular}{|c|c|c|c|c|}
\hline الوجوب والندب & فاعف & فاعف عنهم واصفح & 13 & .5 \\
\hline | الإجابة & فاصطادوا & وإذا حللتم فاصطادوا & 2 & .6 \\
\hline | الإجابة & فكلوا & فكلوا مّّا أمسكن عليكم & 4 & .7 \\
\hline الإستسكار والتعجب & أنظر & أنظر كيف نبين لهم & 75 & .8 \\
\hline الإعتداد & أذكر & أذكر نعمتى عليك & 110 & .9 \\
\hline الإعلام & و اتلوا & واتلوا عليهم نبأ ابنى ءادم & 27 & .10 \\
\hline الإقتضاح والتأييس & واحذرهم & واحذرهم أن يفتنوك & 49 & .11 \\
\hline الإمتثال & اذكروا & اذكروا نعمة الله عليكم & 20 & .12 \\
\hline الإهانة والإهتقار & فاذهب & فاذهب أنت ربك & 24 & .13 \\
\hline الإهانة والإهتقار & فقاتلا & فقاتلا إنا هاهنا قاعدون & - & .14 \\
\hline ال الإهتمام & أدخلوا & أدخلوا الأرض المقدسة & 21 & .15 \\
\hline ال الإهتمام & أدخلوا & أدخلوا عليهم الباب & 23 & .16 \\
\hline التأكيد & فاستبقوا & فاستبقوا الخيرات & 48 & .17 \\
\hline الت أت أكيد & وان احكم & وان احكم بينهم & 49 & .18 \\
\hline التخيير & فاحكم & فإن جاءوك فاحكم بينهم & 42 & .19 \\
\hline التهديد وشدة الوعيد & فاعلموا & فاعلموا أنما على رسولنا & 92 & .20 \\
\hline التهديد وشدة الوعيد & اعلموا & اعلموأن الله شديد العقاب & 98 & .21 \\
\hline 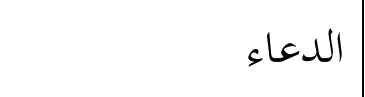 & فافرق & فافرق بينا وبين القوم & 25 & .22 \\
\hline الم الدعاء & فاكتبنا & ربنا آمن فاكتبنا & 83 & .23 \\
\hline 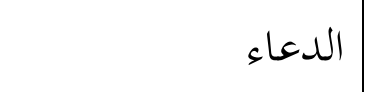 & واشهد & واشهد بأننا مسلمون & 111 & .24 \\
\hline ال الدعاء & أنزل & آللَّهُهَّ رَبَّنَاَ أَنزل عَلَيْنَا & 114 & .25 \\
\hline
\end{tabular}




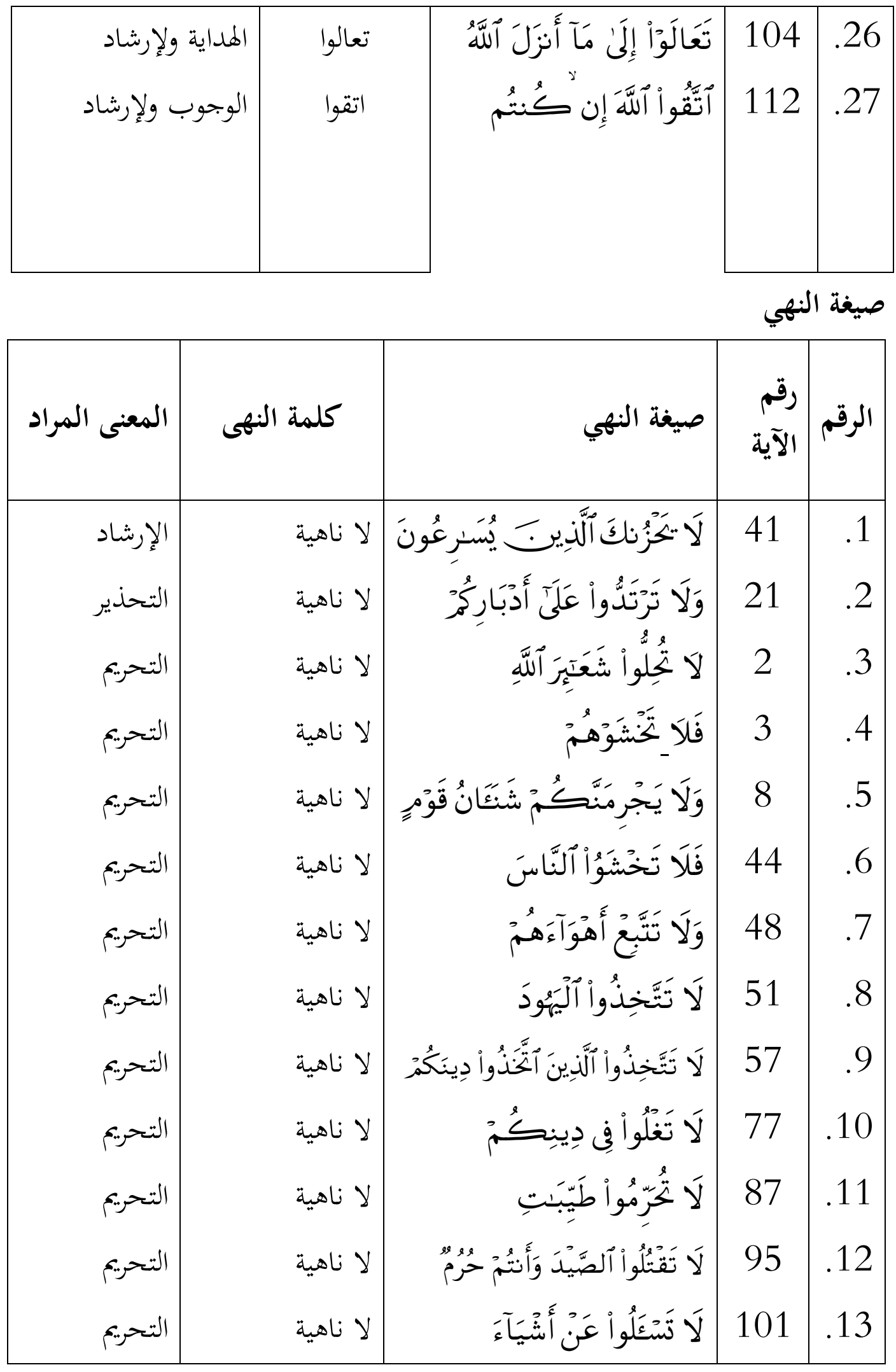




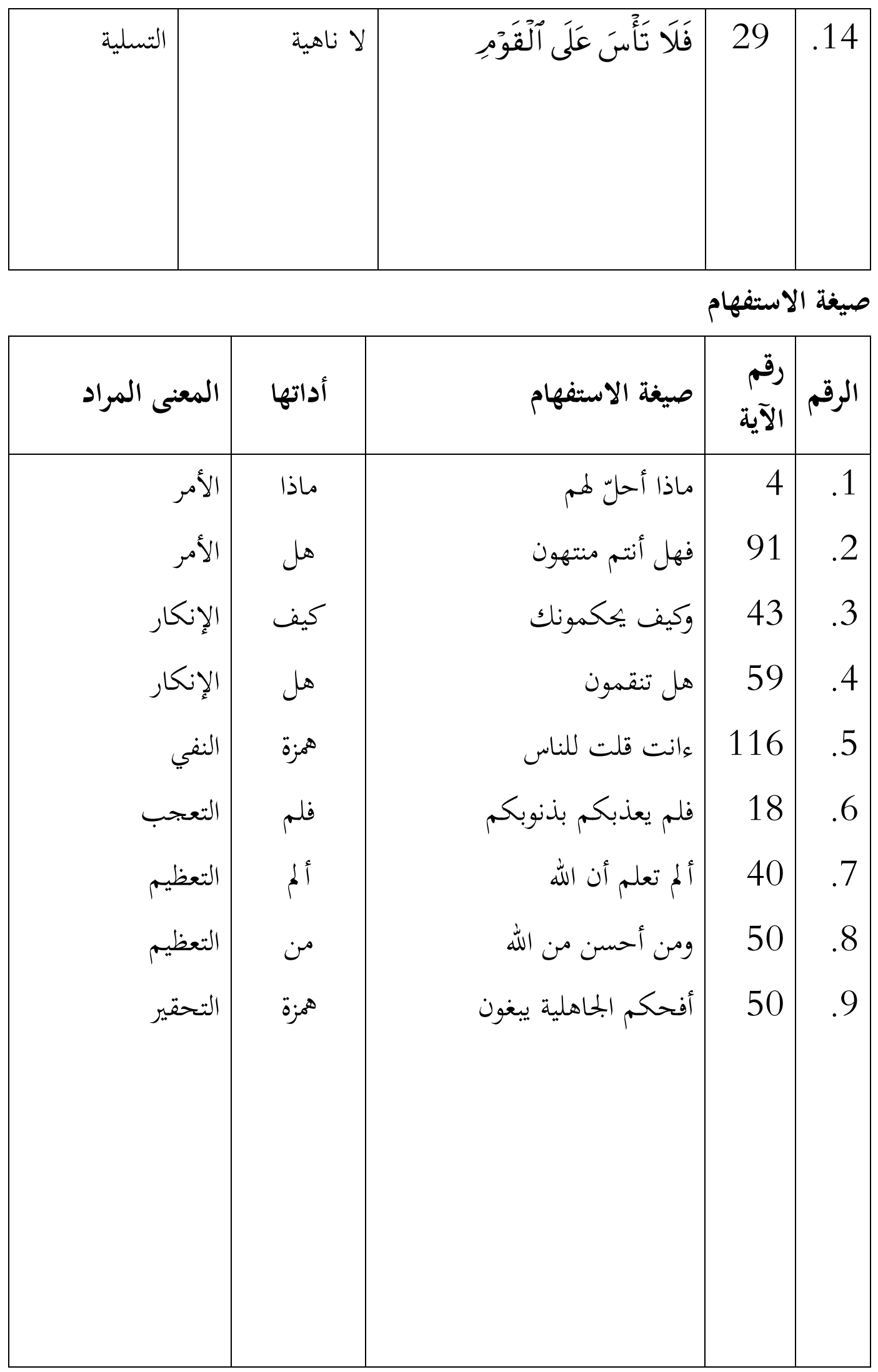




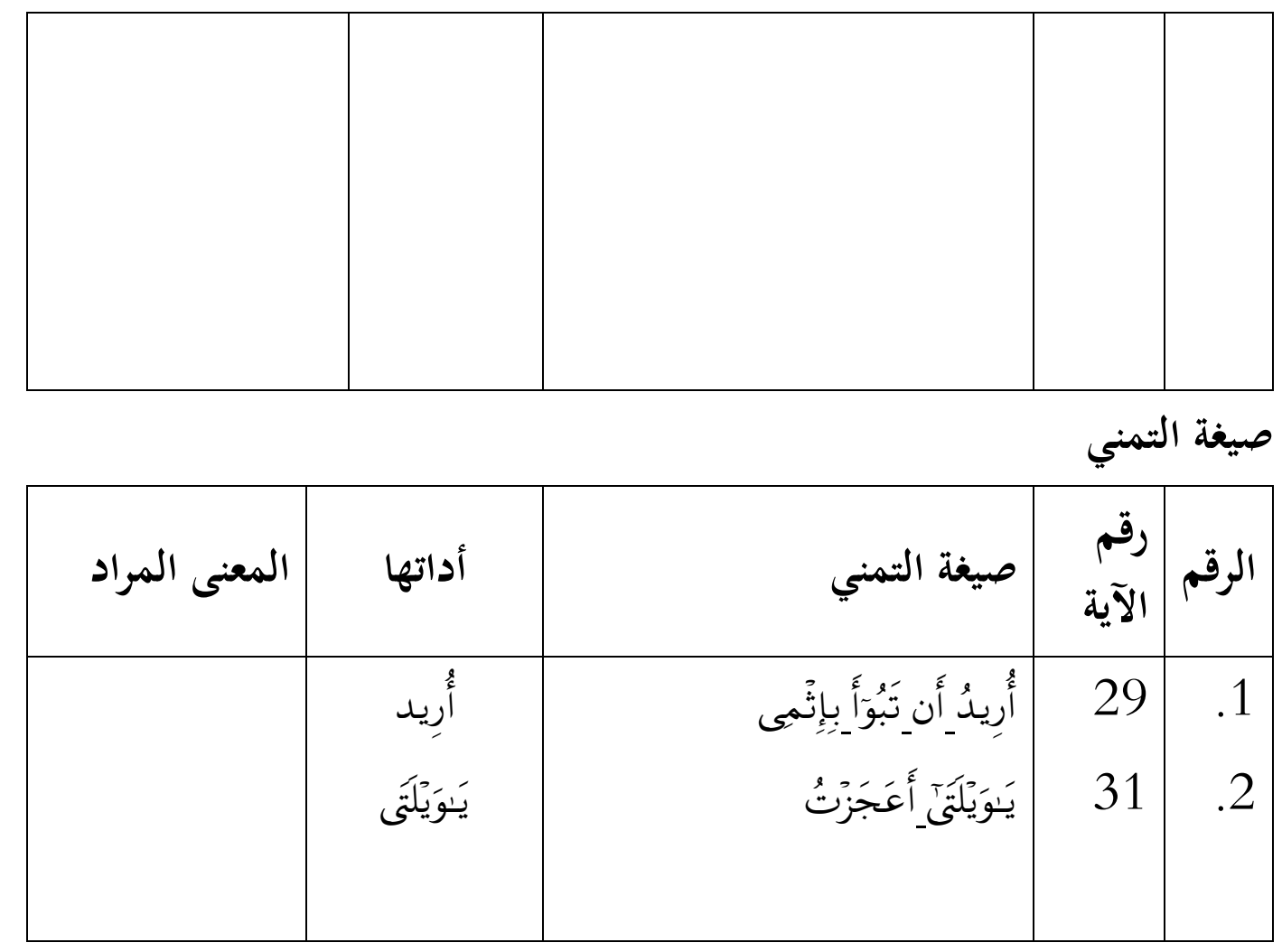

صيغة النداء

\begin{tabular}{|c|c|c|c|c|}
\hline المعنى المراد & اداتها & صيغة النداء & رآلم & الرقم \\
\hline ال الإغراء & يا & يأيّها الذين ءامنوا & 1 & .1 \\
\hline 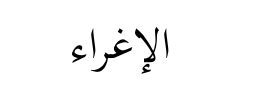 & يا & يأيّها الذين ءامنوا & 6 & .2 \\
\hline ال الإغراء & يا & ياقوم ادخلوا & 21 & .3 \\
\hline ال الإغراء & يا & يأيّها الذين ءامنوا & 25 & .4 \\
\hline الإختصاص & يا & يُأهل الكتاب & 15 & .5 \\
\hline الإختصاص & يا & قالوا ياموسى & 24 & .6 \\
\hline الإختصاص & يا & يأيّها الرسول & 41 & .7 \\
\hline
\end{tabular}




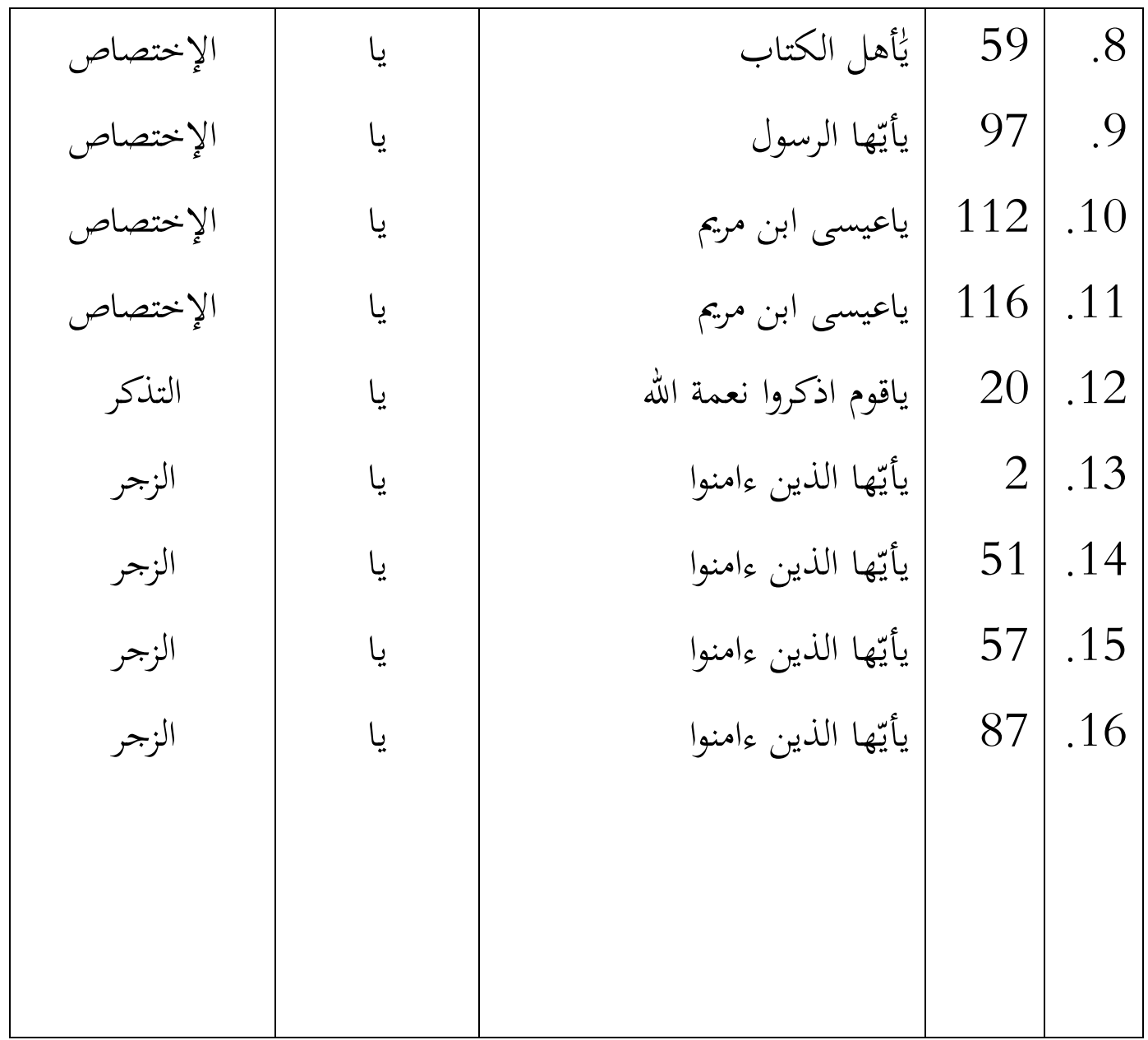

\section{Kesimpulan dan Implikasi Penelitian}

\section{Kesimpulan}

Pada bagian akhir ini, penulis akan mengemukakan beberapa kesimpulan berdasarkan pembahasan terdahulu, kesimpulan-kesimpulan itu antara lain:

1. Surah al-Maidah, memuat ayat-ayat yang mengandung uslüb al-insyäa thalabi yang terdiri atas:
a) Amar (perintah) 27 ayat
b) Nahȳ (larangan 14 ayat
c) Istifhām (pertanyaan) 9 ayat
d) Nidā' (panggilan) 16 ayat
e) Tamanni (harapan) 2 ayat

2. Dalam ayat-ayat yang terdapat dalam surah al-Maidah, peneliti menemukan amar (kata perintah) yang mengandung makna bukan perintah, yaitu 27 ayat. Jumlah tersebut mencangkup semua makna lain amar yang terdiri atas 15 makna, dengan urutan sebagai berikut :
a) الوجوب والندب
5 ayat
h) الإهانة والإهتقار
2 ayat
b) الإجابة
2 ayat
i) الإهتمام
2 ayat 

c) الإستسكار والتعجب
1 ayat
j) التأكيد
2 ayat
d) الإعتداد
1 ayat
k) التخيير
1 ayat
e) الإعلام
1 ayat
1) التهديد وشدة الوعيد
2 ayat
f) الإقتضاح والتأييس
1 ayat
الدعاء (الداء
4 ayat
g) الإمتثال
1 ayat
n) الهداية ولإرشاد الهاء
1 ayat

3. Nahȳ (larangan) yang mengandung makna bukan larangan, yaitu 14 ayat. Jumlah tersebut mencangkup semua makna lain nahy yang terdiri atas 4 makna, dengan urutan sebagai berikut :
a) الإرشاد
1 ayat
b) التحذير
1 ayat
c) التحريم
11 ayat
d) التسلية
1 ayat

4. Istifhām (pertanyaan) yang mengandung makna bukan pertanyaan, yaitu 9 ayat. Jumlah tersebut mencangkup semua makna lain nahy yang terdiri atas 6 makna, dengan urutan sebagai berikut :
a) 2 ayat
d) التعجب التبط
1 ayat
b) الإنكار 2 ayat
e) التعظيم (النعبe
2 ayat
c) 1 ayat
f) التحقير
1 ayat

5. Nida (panggilan) yang mengandung makna bukan panggilan, yaitu 16 ayat. Jumlah tersebut mencangkup semua makna lain nidā yang terdiri atas 4 makna, dengan urutan sebagai berikut :
a) الإغراء
4 ayat
b) 7 ayat
c) التذكر
1 ayat
d) الزجر
4 ayat

6. Peneliti menemukan ayat yang mengandung makna tamanni di dalam surah al-Maidah sebanyak dua ayat, yang terletak pada ayat 29 dan 31.

\section{Implikasi Penelitian}

Temuan penelitian ini dapat memberi dukungan terhadap hasil penelitian sejenis yang telah diadakan sebelumnya dan sekaligus memperkaya hasil penelitian perihal Uslüb al-Insyä' dari aspek ilmu balagah.

Berdasarkan hasil penelitian tersebut, disampaikan saran-saran sebagai berikut (1) hasil penelitian menunjukkan bahwa dalam Surat al-Maidah terdapat ayat-ayat yang mengandung uslub insya dengan berbagai bentuk, maka para peneliti karya sastra hendaknya melakukan penelitian lebih lanjut tentang insya' thalabi maupun insya' ghairu thalabi dalam surat-surat lain yang terdapat dalam al-Quran yang lebih banyak dan lebih panjang, (2) penelitian ini memiliki keterbatasan, baik yang berkaitan dengan datanya, substansi masalahnya, maupun metodenya (model analisisnya). Oleh karena itu, disarankan kepada berbagai 
pihak yang berkompeten dengan ilmu ma'ani maupun tafsir al-Quran untuk melakukan penelitian lanjutan dengan menggunakan data, substansi masalah, dan model analisisnya yang berbeda dan lebih komprehensi

\section{DAFTAR PUSTAKA}

'Aid Rajaa, Falsafah al-Balāgah Baina al-Taqniyyah wa al-Tathawwur (Iskandaria: al-Ma'arif, t.th.).

Al-'Allāf Adib, al-Bayān fi 'Ulūm al-Qur'ān, Juz I (Cet. I; Damaskus: Maktabah al-Farābi, 1999).

Al-Ansāriy Ibn Mansūr Jamāl al-Dīn Muhammad ibn Makram, Lìsān al-'Arab, Juz I (Mesir: Dār al-Kitāb al-‘Arabìy, 1967).

Al-Baehaqiiy Ahmad ibn al-Husain ibn 'Ali ibn Mūsā Abū Bakr, Sunan alBaehaqīy al-Kubrā, Juz VI (Mekah: Maktabah Dār al-Bāz, 1994).

Al-Bāqillāniy Abū Bakr Muhammad Abū al-Tayyib, I'jāz al-Qur'ān (Cet. IV; Kairo: Dār al-Ma'ārif, t.th.).

Al-Fairuzabadi Majd al-Din Muhammad bin Ya'qub, al-Qamūs al-Muhit Murattaban Tartīban Alfabaian Wifqa Awāil al-Hurūf, ed. Anas Muhammad as-Syami dan Zakariya Jabir Ahmad (Cairo: Dar al-Hadis, 2008).

Al-Hāsyimi Ahmad', Jawāhir al-Balagah al-Ma’ānì wa al-Bayān wa al-Badì (Cet. XVIII; Indonesia: Maktabah Dār Ilhyā' al-Kutub al-'Arabiyyah, 1960).

Al-Hāsyimi al-Sayyid Ahmad, al-Qawāid al-Asāsiyyah fi al-Lugah al-'Arabiyyah (Beirut: Dār al-Kutub al-'Ilmiyyah, t.th.).

Al-Hāsyimīy al-Sayyid Ahmad, Jawāhir al-Balāgah (Beirut: Dār al-Fikr, 1994).

Al-Haufîy Ahmad Muhammad, al-Adab al-'Arabìy wa Tārikhuhū (Kairo: Dār al-Ma'ārif, 1977).

Al-Ja'fiy Muhammad ibn Ismā'il Abū 'Abdillah al-Bukhāriy, Sāhih al-Bukhārìy, Juz IV (Cet. III; Beirut: Dār Ibn Kasīr, 1987).

Al-Jamāl 'Abdul Mun'im, al-Tafsìr al-Farīd li al-Qur'ān al-Majīid, Jilid VII (tanpa data).

Al-Jārim Ali dan Mustāfa Amīn, al-Balāgah al-Wādihah; al-Bayān, al-Ma'āni, alBadi' (Damaskus: Maktabah al-Asad, 1999).

Al-Jārim Alì dan Mustafā Amīn, al-Balāgah al-Wādihah (Cet. X; Mesir: Dār alMa'ārif, 1951).

Al-KhāTiq Rabì'iy Muhammad 'Ali 'Abd, al-Balāgah al-'Arabiyyah wasāiluhā wa Gāyatuhā fí al-Taswìr al-Bayānīy (Alexandria: Dār al-Ma'rifah alJāmi'iyyah, 1989). 
Al-Khūliy Amin, Asālib al-Lugah al- 'Arabiyyah, Volume II (Kairo: Dār al-Kutub al-'Ilmiyyah, 1994).

Al-Maidani Abd. Al-Rahman Hasan Habannakah, al-Balāgah al-'Arābiyyah; Usūsuhā wa 'Ulūmuhā wa Funūnuhā, Jilid I (Damaskus: Dar al-Qalam, 1996).

Al-Marāgìy Ahmad Nustafā, Tarīkh 'Ulūm al-Balāgah wa al-Ta'rīf bì Rijàlihā (Cet. I; Kairo: Mustafā al-Babīy al-Halibìy wa Aulāduh, 1950).

Al-Munawwar Said Aqil dan Masykut Hakim, I'jaz Alquran dan Metodologi Tafsir (Cet XI; Semarang: Dina Utama, 2000).

Al-Nasabūrìy Abi al-Hasan 'Ali ibn Ahmad al-Wāhidiy, Asbāa al-Nuzūl (Cet. II; Kairo Matba'ah Mustafa al-Bāb al-Halabīy wa Awlāduh, 1965).

Al-Qandaniy Abi Fatih Machfuzhi, Intisari Ilmu Balagah (Yogyakarta: Lentera Kreasindo, 2015).

Al-Qazwaini Al-Khatib, al-Idāh fí Ulūm al-Balāgah, Syarah Dan Komentar Oleh Muhammad 'Abd al-Mun'im Khalafaji, juz I.

Al-Rafí'ìy Mustāfā Sādiq, I'jaz al-Qur'ān wa al-Balāgah al-Nabawiyyah (Cet. VIII; Beirut: Dār al-Kitāb al-'Arabiy, t.th.).

Al- Subhīy Muhammad 'Ali, al-Mu'allaqāt al-Asyr (Beirut: Dār al-Fikr, 1978).

Al-Syāfi'ìy Ahmad ibn 'Ali ibn Hajar Abū al-Fadl al-'Asqalānìy, Fats al-Bāri, Juz VIII (Beirut: Dār al-'Ilmiyyah, 1978).

Al-Sya'rāwiy Muhammad Mutawalli, Mu'jizat al-Qur'ān, Kitab I (Kairo: Maktabah al-Turās al-Islāmīy, t.th).

Al-Zamakhsyarìy Jārullah Abū al-Qāsim Mahmūd ibn 'Umar, Asās al-Balāgah (Beirut : Dār al-Fikr, 1989).

Al-Zarkasyiy Al-Imam Badar al-Din Muhammad Ibnu Abdullah (selanjutnya disebut al-Zarkasyiy), al-Burhān fi Ulüm al-Qur'ān, Juz III.

Al-Zarqāniy Muhammad Abd al-'Azim, Manāhil al-'Irfan fi Ulūm al-Qur'ān, Juz II (Cet.I Beirut: Dār al-Ilhya al-Turaa al-'Arabiy).

Amīn Bakrī Syekh, al-Ta’bìr al-fannìy fi al-Qur'ān (Cet II; Beirut: Dār alSyurūq, 1994).

Ashhiddiqi Hasbi dkk, Al-Qur'an dan terjemahannya Kedalam Bahasa Indonesia. (Arab Saudi: Riyad, 1971).

Badara Aris , Wacana Teori Metode dan Penerapannya pada Wacana Media, (Cet. III; Jakarta: Kencana, 2014).

Brown Yule dan Gillianm, Analisis Wacana (Jakarta: Gramedia 1996).

Departemen Pendidikan dan Kebudayaan, Kamus besar Bahasa Indonesia, Edisi II (Cet. III; Jakarta Balai Pustaka, 1994), h 37. 
Dūd Rābih, al-Balāgah 'inda al-Mufassirin hattā Nihāyat al-Qarn al-Rābi’ alHijrìy (Cet. I; Kairo: Dār al-Fajr li al-Nasyr wa al-Tauzi', 1997).

Echols John M. dan Hasan Shadily, Kamus Inggris-Indonesia (Cet. XXIII;Jakarta: PT. Gramedia Pustaka Utama, 1996).

Hasan 'Abdullāh 'Ali Muhammad, al-Bahs al-Balāgìy wa Marāhil Tathawwuri (Cet.I; Kairo: Matba’ah al-Amānah, 1993).

'Id Rajā', Falsafah al-Balägah Baena al-Taqniyah wa al-Tatawwur (Cet. II; Alexandria: Mansya'ah al-Ma'ārif, t.th.).

Ismā'il Muhammad Bakr, Dirāsah fi Ulūm al-Qur'ān (Cet. I; Kairo: Dār Nahdah Misr fi al-tibā'ah wa al-Nasyr, t.th.).

Kātib Mulla, Kasyf al-Zunūn, Volume II (Kairo: Dār al-Tibā'ah al-Misriyyah, $274 \mathrm{H})$.

Khaldūn Abd Rahmān Ibn, Muqaddimah (Cet. IV; Beirut: t.tp., t. th.).

Mardalis, Metode Penelitian (suatu Pendekatan Proposal) (Cet. IX; Jakarta: PT.Bumi Aksara, 2007).

Mūsa Muhammad Abū-, al-Balāgah al-Qur'āniyyah fi Tafsìr al-Zamaksyarī wa Asaruha fi al-Dirāsat al-Balāgiyyah (Cet. II; Kairo: Maktabah Wahbah, 1988).

Muslim Mustafa, Mabāhis fi I'jāz al-Qur'ān (Cet. III; Damaskus: Dār al-Qalam, 1999).

Qalqilah Abduh Abd al-Aziz, al-Balaḡat al-Istilāhiyyat (Cet. III; Cairo: Dar alFikr al-Arabi, 1992).

Qutb Sayyid, al-Thaswìr al-Fannìy fi al-Qur'ān (Kairo: Dār al-Ma'ārif, 1976).

R. Ilham Khoiri, Alquran dan Kaligrafi Arab (Cet. XX; Jakarta: Logos, 2001).

Sālih Abd al-Quddūs Abū dan Ahmad Taufiq Kulai, 'Ilm al-Bayān (Cet. I: Saudi Arabia: Idārat Tatawwur al-Khutat wa al-Manāhij Jāmi'ah al-Imām Muhammad ibn Su'ud al-Islāmiyyah, 1406 H.).

Shihab M. Quraish, Tafsir al-Misbah, Pesan, Kesan, dan Keserasian al-Qur'an. (Cet. IX, Vol. 3; Jakarta: Lentera Hati, 2007).

Sibawayh, al-Kitab, di-tahqīq oleh ‘ Abd al-salām Muhammad Hārūn, Volume III (Beirut: Dār al-Jil, t.th.).

Soejono dan H. Abdurrahman, Metode Penilitian: Suatu Pemikiran dan Penerapan (Cet. I; Jakarta: Rineka Cipta, 1999).

Titscher Stefan dkk., "Method of Text and Discorse Analysis", diterjemahkan oleh Ghazali dkk., dengan judul Metode Analisis Teks dan Wacana (Cet. I; Yogyakarta: Pustaka Pelajar, 2009).

Wahbah Majdi dan Kamil al-Muhandis, Mu'jam al-Mustalahät al- Arabiyyah fí al-Lugati wa al-Adab (Cet. II; Beirut: Maktabah Lunan, 19840. 
Zainuddin Mamat dan Yayasan Nurbayan, Pengantar Ilmu Balagah (Bandung: RefikaAditama, 2007). 